in grazed and ungrazed forage species. Agronomy Journal 66:10-12.

Nie, N. H., C. H. Hull, J. G. Jenkins, K. Steinbrenner, and D. H. Bent. 1975. Statistical package for the social sciences. Second edition. McGraw-Hill, New York, New York, USA.

Smith, G. S., A. B. Nelson, and E. J. A. Bogino. 1971. Digestibility of forages in vitro as affected by content of "silica." Journal of Animal Science 33:466-471.

Van Soest, P. J. 1982. Nutritional ecology of the ruminant. O\&B Books, Corvallis, Oregon, USA.
${ }^{1}$ Manuscript received 30 August 1985; revised 30 December 1985; accepted 27 January 1986.

${ }^{2}$ Natural Resource Ecology Laboratory and Department of Range Science, Colorado State University, Fort Collins, Colorado 80523 USA.

${ }^{3}$ Permanent address: Universidad Nacional de Mar del Plata, Balcarce, Argentina.
Ecology, 67(4), 1986, pp. 1101-1105

(C) 1986 by the Ecological Society of America

\section{POLLEN IN LAMINATED SEDIMENTS PROVIDES EVIDENCE FOR A MID-HOLOCENE FOREST PATHOGEN OUTBREAK ${ }^{1}$}

\author{
Taber D. Allison, ${ }^{2}$ Robert E. Moeller, ${ }^{3}$ and \\ Margaret Bryan Davis ${ }^{2}$
}

The populations of two major forest tree species, American chestnut (Castanea dentata) and American elm (Ulmus americana), have been devastated by pathogens introduced in this century (Kuhlman 1978, Sinclair and Campana 1978, Anagnostakis 1982). The fossil pollen record in eastern North America shows a rapid decline of eastern hemlock (Tsuga canadensis) $4850{ }^{14} \mathrm{C}$ yr BP and may be evidence for a catastrophic pathogen outbreak similar to the chestnut blight and Dutch-elm epidemics.

Davis (1981) hypothesized that the prehistoric decline of hemlock was caused by the outbreak of a pathogen similar in epidemiology to the exotic pathogens that devastated chestnut and elm. Three lines of evidence supported the pathogen hypothesis. First, the decline was synchronous throughout the range of hemlock, within the limits of precision of ${ }^{14} \mathrm{C}$ dating (Davis 1981, Webb 1982). Second, the decline occurred throughout a $1.5 \times 10^{6} \mathrm{~km}^{2}$ region where different climatic factors limited hemlock's growth and reproduction. For example, the decline occurred in the mountains of New Hampshire, where hemlock is limited to the warmest part of the elevational gradient (Davis et al. 1980), and in Michigan, where moisture is apparently limiting (Brubaker 1975). Third, the concentra- tion of pollen of successional trees, such as birch (Betula spp.), increased in sediment deposited immediately after the decline and was followed by increased pollen from trees that competed with hemlock in mature forest: maple (Acer spp.) and beech (Fagus grandifolia) in northern New Hampshire, oak (Quercus spp.) and eastern white pine (Pinus strobus) in southern New Hampshire, and white pine and other conifers in northern Michigan. These changes are analogous to the historically documented increases in first birch and then oak pollen in Connecticut sediment following the chestnut blight (Brugam 1978, Davis 1981, 1983).

In order to test the pathogen hypothesis further, we compared the rapidity of the hemlock pollen decline with the decline of chestnut pollen recorded in the laminated sediments of Pout Pond in Belmont County, New Hampshire $\left(43^{\circ} 25^{\prime} \mathrm{N}, 71^{\circ} 30^{\prime} \mathrm{W}\right)$. The link between the chestnut blight of the early decades of the 20 th century and a decline in chestnut pollen percentages in recently deposited lake sediment is well established (Anderson 1974). We used the fine-scale stratigraphy at Pout Pond to measure chestnut's pollen response to its pathogen and to calibrate the time sequence expected at that site for a fossil record of pathogen attack.

Chestnut was nearly exterminated by the fungus $E n$ dothia parasitica, which was initially detected in 1904 in New York City and reached southern New Hampshire in the 1920's. Spreading rapidly, the fungus eliminated virtually all living chestnut trees from the forests of eastern North America within a few decades (Anderson 1974). Shoots continue to sprout from the rootstock of chestnut but are attacked by the still-endemic fungus; the shoots seldom grow large enough to flower (Kuhlman 1978, Anagnostakis 1982).

Local demise of chestnut near Pout Pond was recorded in a $47 \mathrm{~cm}$ long sequence of surficial sediment removed from $20 \mathrm{~m}$ of water with a frozen-crust corer 


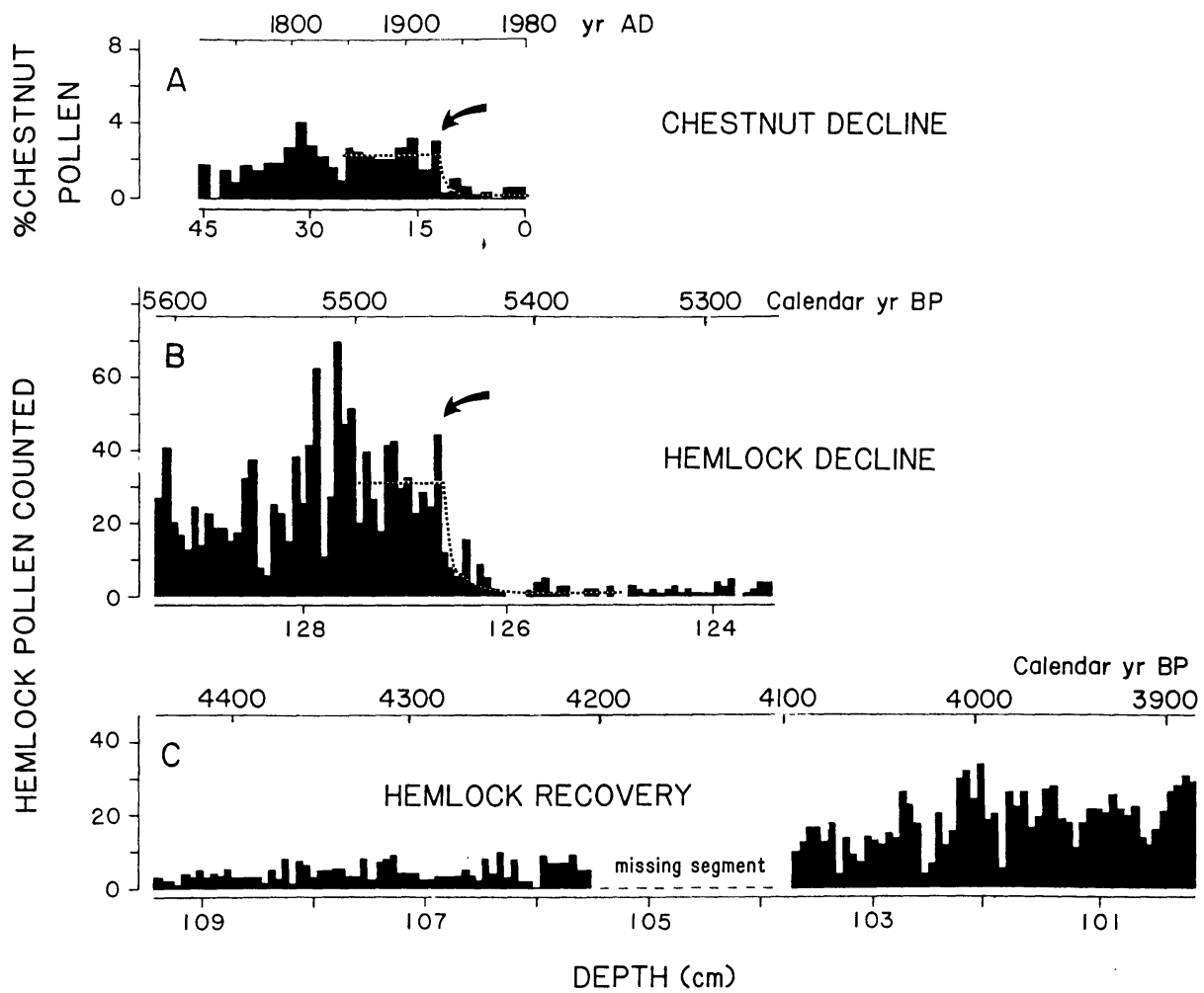

Fig. 1. (A) Chestnut pollen, as percent of total tree pollen, versus depth at Pout Pond, New Hampshire, before and after the introduction of the chestnut blight (indicated by arrow). Samples 1-2 cm thick were prepared from a frozen core using standard pollen analysis techniques. The smoothed curve (dotted line) traces a $75 \%$ decrease within $5 \mathrm{yr}$. The age scale is not linear, reflecting the change in sediment compaction with depth. (B) Hemlock pollen grains versus depth for the region of the hemlock decline. Hemlock pollen was counted along transects across thin sections that were cut perpendicular to the bedding plane of embedded sediment. The smoothed curve (dotted line) corresponds to a 75\% decrease within 7-8 yr. The arrow indicates the beginning of the hemlock decline at $126.66 \mathrm{~cm}$ depth. (C) Hemlock pollen grains versus depth in thin cross sections of embedded sediment from the region of hemlock recovery. The data in (B) and (C) are counts from one transect at each depth, but are not directly comparable, as statistically significant differences exist between lamination thicknesses in thin sections from these sampling levels. Each count in (B) includes, on average, 3.8 laminations, while each count in (C) includes, on average, 4.2 laminations. The calendar year age scales for (B) and (C) are approximations determined by interpolating between radiocarbon dates calibrated in calendar years (Klein et al. 1982). Occasional gaps occur in the count sequence of (B) and (C) due to separation of sediments during the embedding process or due to previous removal of sediment for pollen analysis (T. D. Allison, personal observation).

(Swain 1973). Sediment in the frozen core was laminated in the upper $10 \mathrm{~cm}$ (estimated age $0-30 \mathrm{yr}$ ) and at levels deposited before settlement in $1810 \mathrm{AD}$. Contiguous segments of sediment $1-2 \mathrm{~cm}$ thick were cut from the core and prepared for pollen analysis according to the methods of Faegri and Iverson (1975). Pollen was counted in transects across microscope slides at $640 \times ; \approx 350$ arboreal pollen grains were counted on each slide.

Chestnut pollen percentages fell from $3 \%$ to $<0.5 \%$ of total tree pollen, and chestnut pollen concentrations declined from 46000 to 5700 grains/g dry mass, at $11.5 \mathrm{~cm}$ below the surface. The decline in chestnut pollen deposition occurred between samples that differ in mean age by 7-8 yr (Fig. 1A).
Data similar to those from Pout Pond were obtained from Linsley Pond, Connecticut (Brugam 1978); in both sites the absence of benthic invertebrates preserved fine-scale stratigraphy. In the Linsley Pond core, chestnut pollen averaged $8.8 \%$ of total tree pollen in samples from $30-70 \mathrm{~cm}$ depth. It dropped from this value at $30 \mathrm{~cm}$ to $1.7 \%$ of total tree pollen at $27 \mathrm{~cm}$ depth; this $3-\mathrm{cm}$ depth interval was estimated to cover $9 \mathrm{yr}$. The percentage of chestnut pollen remained low $(\bar{X}=1.8 \%)$ throughout the younger sediments $(27-0 \mathrm{~cm}$ ) (Brugam 1978 and personal communication).

Given these results for the decline of chestnut, we hypothesized that a decline in hemlock fossil pollen deposition within 7-9 yr would support the hypothesis that a pathogen or similar agent was involved. Previous 
TABLE 1. Summary of radiocarbon dates for sample depths included in the pollen diagrams of Pout Pond and Mirror Lake, New Hampshire (Fig. 3).

\begin{tabular}{cccr}
\hline $\begin{array}{c}\text { Sample } \\
\text { no. }\end{array}$ & Depth $(\mathrm{cm})$ & \multicolumn{1}{c}{$\begin{array}{c}{ }^{14} \mathrm{C} \text { age } \\
(\mathrm{yr} \text { BP })\end{array}$} & $\begin{array}{c}\text { Age } \\
\text { (calendar years)* }\end{array}$ \\
\hline \multicolumn{4}{c}{ Pout Pond } \\
GX-8492 & $82-84$ & $2710 \pm 145$ & $790-1045 \mathrm{BC}$ \\
GX-8494 & $149-151$ & $5995 \pm 180$ & $4585-5220 \mathrm{BC}$ \\
\multicolumn{4}{c}{} \\
I-5394 & Mirror Lake \\
I-5395 & 400 & $3170 \pm 155$ & \\
I-4732 & 600 & $3750 \pm 180$ & \\
\end{tabular}

* The $90 \%$ confidence interval of the equivalent age in calendar years (Klein et al. 1982).

pollen analyses of Pout Pond sediment (Davis 1981; T. D. Allison, personal observation) showed a decline of hemlock pollen percentage from $23 \%$ of total pollen to $10 \%$ between 126 and $127 \mathrm{~cm}$, coupled with a $72 \%$ decline in hemlock pollen concentration (from 153000 grains $/ \mathrm{cm}^{3}$ to 43500 grains $/ \mathrm{cm}^{3}$ ). The estimated age at this depth, based on interpolation between radiocarbon-dated samples (Table 1), is 4867 radiocarbon yr BP. The age estimate agrees closely with dates of the decline recorded in other lakes and bogs (Davis 1981, Webb 1982).

We obtained a detailed record of these changes by examining the laminae within the Pout Pond core. Cubes of sediment were removed from various depths in the core and embedded in Carbowax PEG 1000 (Tippett 1964). Thin sections $(30 \mu \mathrm{m})$ were cut perpendicular to the bedding plane of the laminae with a microtome and mounted in immersion oil on slides for viewing under a light microscope.

Laminations deposited between $83 \mathrm{~cm}$ and $150 \mathrm{~cm}$ (including the hemlock decline at $127 \mathrm{~cm}$ ) are couplets $100-200 \mu \mathrm{m}$ thick consisting of a layer of dinoflagellate and chrysophyte cysts and a layer of pollen-containing organic sediment (Fig. 2). The annual periodicity of the laminations is confirmed by the agreement between the number of couplets between 83 and $150 \mathrm{~cm}$ depth ( 3848 couplets; SD of estimate $=70.3$ ) and the number of calendar years $(3540-4430$ years; midpoint $=3935)$. The latter was determined from the difference between the $90 \%$ confidence intervals of the calendar year equivalents of radiocarbon dates at $83 \mathrm{~cm}$ and $150 \mathrm{~cm}$ depths (Table 1) (Klein et al. 1982). We estimated the total number of laminations between $83 \mathrm{~cm}$ and 150 $\mathrm{cm}$ by counting couplets per millimetre thickness in thin sections from six $1 \mathrm{~cm}$ thick samples collected at $\approx 10$-cm intervals. A mean sedimentation rate (in years per millimetre) was determined for each sample; the number of years elapsed between samples was estimated by interpolating between two sample depths.

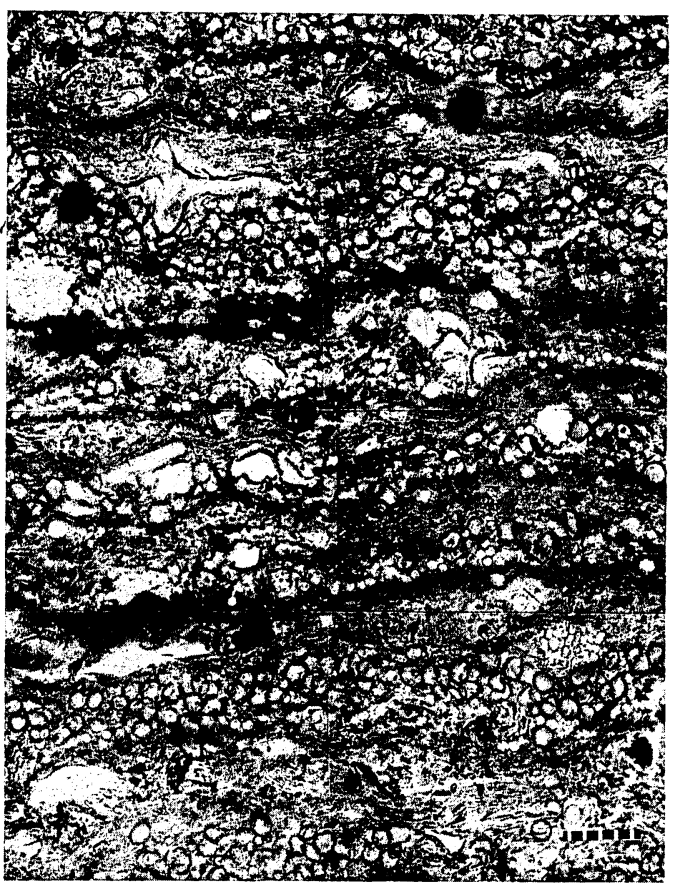

FIG. 2. Thin section of laminated sediment from Pout Pond, New Hampshire, showing $>7$ yr deposition of dinoflagellate and chrysophyte cysts. Dotted line equals $100 \mu \mathrm{m}$. (Taber D. Allison, University of Minnesota, Minneapolis, Minnesota, USA.)

We determined the detailed stratigraphy of the hemlock decline by counting hemlock pollen in situ on thin sections. Hemlock pollen was tabulated along transects whose length ran parallel to the bedding plane of the laminations. The transect height (the diameter of the microscope field) included 3-4 laminations. Hemlock pollen was identified by shape and wall sculpturing. Each of our pollen counts is the number of pollen grains in one transect, and represents deposition over 3-4 yr. Pollen counts are equivalent to concentrations in a volume of sediment equal to $0.03 \mathrm{~mm}$ (the thickness of the thin section) $\times 0.65 \mathrm{~mm}$ (the transect height) $\times$ $10 \mathrm{~mm}$ (the length of the transect).

Pollen influx (grains per square centimetre per year) can be calculated by dividing pollen counts by the sedimentation rate (in laminations per unit transect height). For example, we estimated a sedimentation rate of 5.9 laminations $/ \mathrm{mm}$ at the depth of the hemlock decline. Each transect, $0.65 \mathrm{~mm}$ high, contained an average of 3.8 laminations (years). A count of 36 hemlock pollen grains per transect, therefore, was equivalent to 9.5 pollen grains $\cdot 0.3 \mathrm{~mm}^{-2} \cdot \mathrm{yr}^{-1}$. If one assumes a uniform distribution of pollen in the cube of sediment from which the thin section was made, this deposition rate can be converted directly to an influx value: 3167 grains. 


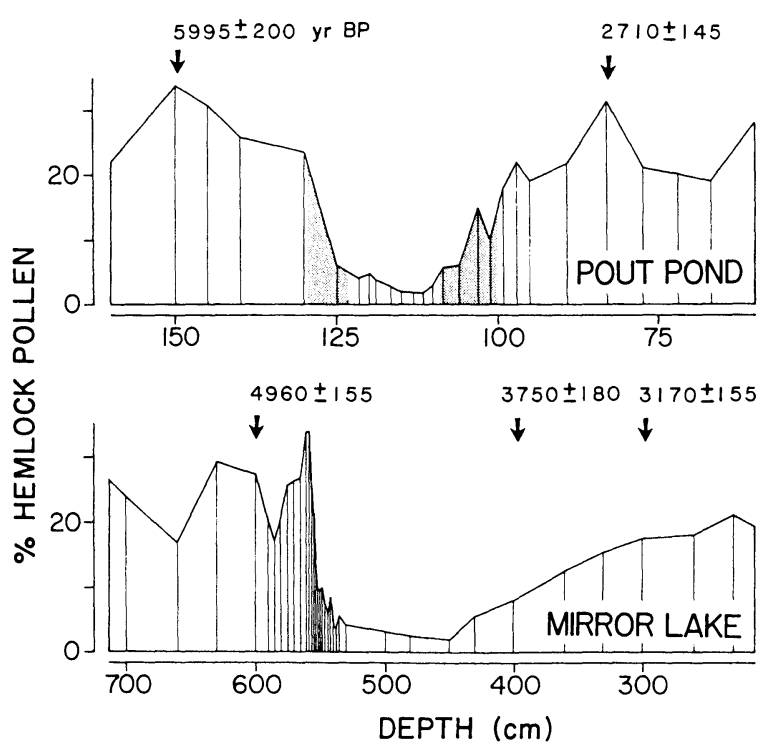

FIG. 3. Percent hemlock pollen versus depth at Pout Pond and Mirror Lake, New Hampshire. Percentages are based on analysis of $1-\mathrm{cm}^{3}$ samples prepared by standard techniques (Faegri and Iversen 1975). Solid vertical lines in the diagram indicate sampling depths. The shaded portions of the Pout Pond diagram correspond to the depths used for thin-section counts (Fig. 1B and C). The Mirror Lake diagram includes previously unpublished counts from closely spaced samples from the core. The arrows indicate radiocarbon dates (years BP) reported in Table 1 .

$\mathrm{cm}^{-2} \cdot \mathrm{yr}^{-1}$. This figure is higher than that for the influx of hemlock pollen ( 2500 grains $\cdot \mathrm{cm}^{-2} \cdot \mathrm{yr}^{-1}$ ) estimated from $1-\mathrm{cm}^{3}$ samples using conventional pollen analysis techniques (T. D. Allison, personal observation). Our result is not surprising, however, because hemlock grains that extended beyond the plane of the thin section were sectioned and counted, enlarging the effective sampling width of the thin section.

The mean number of hemlock pollen grains per transect decreased by $75 \%$ within a $7-8$ yr period (Fig. 1B); this is comparable to the rate of decline of chestnut pollen observed in younger sediment from Pout and Linsley Ponds. Hemlock pollen was rare in Pout Pond sediment deposited 100 or more years after the initial decline, but hemlock pollen persisted until the beginning of the recovery, recorded at the $103-106 \mathrm{~cm}$ depth interval. This pollen may represent continued local presence of hemlock at low densities.

Pre-decline levels of hemlock pollen deposition were again reached at $97 \mathrm{~cm}, \approx 500 \mathrm{yr}$ after the recovery began and $1900 \mathrm{yr}$ after the initial decline (Figs. 1C, 3 ). The recovery of hemlock pollen was much slower than its previous decline. Davis (1981) suggested that evolutionary changes were responsible for the recovery-either the development of host resistance or an attenuation of pathogen virulence analogous to the hypovirulent strain of the chestnut pathogen (Anagnostakis 1982).

Pollen counts per transect in Fig. 1B and C are not directly comparable, as sedimentation rate was 6.5 laminations/mm during the recovery, compared to an average 5.9 laminations $/ \mathrm{mm}$ at the depth of the decline. This difference results in slightly inflated pollen counts per transect during the recovery compared to counts made at depths before and during the decline. In terms of annual hemlock pollen deposition, a count of 20 grains per transect at the depth of the recovery would be equivalent to 18 grains per transect at the depth just before the decline. Thus, hemlock pollen influx at $101 \mathrm{~cm}$ depth (1580 grains $\left.\cdot \mathrm{cm}^{-2} \cdot \mathrm{yr}^{-1}\right)$ was lower than the deposition rate just before the decline (3167 grains $\cdot \mathrm{cm}^{-2} \cdot \mathrm{yr}^{-1}$ ).

The rapidity of the hemlock decline has not been observed previously because lake sediments seldom retain fine-scale stratigraphy. For example, although the hemlock pollen stratigraphies of Pout Pond and Mirror Lake, New Hampshire, are similar (Likens and Davis 1975, Davis 1981), sediment mixing has destroyed the detailed record at Mirror Lake. The decline in hemlock pollen deposition at Mirror Lake is spread over $35 \mathrm{yr}$ despite a rapid rate of sediment deposition $(7-8 \mathrm{yr} / \mathrm{cm})$ and sampling at contiguous $1-\mathrm{cm}$ intervals (Fig. 3). Experimental studies at Mirror Lake by Moeller et al. (1984) show that biological mixing now extends $7 \mathrm{~cm}$ below the sediment-water interface; these studies predict that an instantaneous change in pollen deposition would be recorded as a gradual change over 4$8 \mathrm{~cm}$ of sediment, equivalent to $30-60 \mathrm{yr}$.

The rapid decline in hemlock pollen observed in the laminated sediments of Pout Pond, and its similarity to the recent decline of chestnut pollen, are strong circumstantial evidence for the pathogen hypothesis. The spontaneous appearance of a serious forest pathogen presents an interesting contrast to the chestnut blight, which was introduced to North America by humans. The recovery of hemlock pollen $2000 \mathrm{yr}$ after its decline suggests that natural processes might eventually result in a similar population recovery of chestnut.

Acknowledgments: We thank R. Brugam for the use of his data from Linsley Pond. We also thank E. J. Cushing, A. A. Middledorp, M. Schwartz, D. Cook, R. Calcote, R. N. Mack, and two anonymous reviewers for their comments, which greatly improved this manuscript. Funding was provided by the National Science Foundation, DEB 80-12159.

\section{Literature Cited}

Anagnostakis, S. L. 1982. Biological control of chestnut blight. Science 215:466-471. 
Anderson, T. W. 1974. The chestnut pollen decline as a time horizon in lake sediments in eastern North America. Canadian Journal of Earth Sciences 11:678-685.

Brubaker, L. B. 1975. Postglacial forest patterns associated with till and outwash in northcentral upper Michigan. Quaternary Research 5:499-527.

Brugam, R. B. 1978. Human disturbance and the historical development of Linsley Pond. Ecology 59:19-36.

Davis, M. B. 1981. Outbreaks of forest pathogens in forest history. Pages 216-227 in Proceedings of the IV International Palynological Conference (1976-77), volume 3. Birbal Sahni Institute of Paleobotany, Lucknow, India.

1983. Holocene vegetational history of the eastern United States. Pages 166-181 in H. E. Wright, Jr., editor. The Holocene. Volume 2, Late-Quaternary environments of the United States. University of Minnesota Press, Minneapolis, Minnesota, USA.

Davis, M. B., R. W. Spear, and L. C. K. Shane. 1980. Holocene climate of New England. Quaternary Research 14: 240-250.

Faegri, K., and Iversen, J. 1975. Textbook of pollen analysis. Hafner, New York, New York, USA.

Klein, J., J. C. Lerman, P. E. Damon, and E. K. Ralph. 1982. Calibration of radiocarbon dates: tables based on the consensus data of the Workshop on Calibrating the Radiocarbon Time Scale. Radiocarbon 24:103-150.

Kuhlman, E. G. 1978. The devastation of American chestnut by blight. Pages 1-3 in W. L. MacDonald, F. C. Cech, J. Luchok, and C. Smith, editors. Proceedings of the American Chestnut Symposium. West Virginia University Press, Morgantown, West Virginia, USA.
Likens, G. E., and M. B. Davis. 1975. Post-glacial history of Mirror Lake and its watershed in New Hampshire, USA: an initial report. Internationale Vereinigung für Theoretische und Angewandte Limnologie Verhandlungen 19:982993.

Moeller, R. E., F. Oldfield, and P. G. Appleby. 1984. Biological sediment mixing and its stratigraphic implications in Mirror Lake (New Hampshire, U.S.A.). Internationale Vereinigung für Theoretische und Angewandte Limnologie Verhandlungen 22:562-572.

Sinclair, W. A., and R. J. Campana. 1978. Development and status of Dutch elm disease. Search Agriculture (Geneva, New York) 8:5-6.

Swain, A. 1973. A history of fire and vegetation in northeastern Minnesota as recorded in lake sediments. Quaternary Research 3:383-396.

Tippett, R. 1964. An investigation into the nature of the layering of deep-water sediments in two eastern Ontario lakes. Canadian Journal of Botany 42:1693-1709.

Webb, T., III. 1982. Temporal resolution in Holocene pollen data. Pages 569-572 in Proceedings of the Third North American Paleontological Convention, Volume 2. Business and Economic Service, Toronto, Ontario, Canada.

${ }^{1}$ Manuscript received 1 August 1985; revised 23 January 1986; accepted 24 January 1986.

${ }^{2}$ Department of Ecology and Behavioral Biology, University of Minnesota, Minneapolis, Minnesota 55455 USA. ${ }^{3}$ Academy of Natural Sciences of Philadelphia, Philadelphia, Pennsylvania 19103 USA. 